\title{
Assessment of Heavy Metal Amounts of Spinach Plants (Spinach Oleracea L.) Grown on Cd and Chicken Manure Applied Soil Conditions
}

\author{
Hakan Çelik ${ }^{1 *}$, Sita Sanele Kunene ${ }^{2}$ \\ ${ }^{1}$ Department of Soil Science and Plant Nutrition, Faculty of Agriculture, Bursa Uludag University, Bursa 16059, Turkey \\ ${ }^{2} \mathrm{MSc}$ Student Department of Soil Science and Plant Nutrition, Institute of Natural and Applied Science, \\ Bursa Uludag University, Bursa 16059, Turkey
}

Received: 25 May 2020

Accepted: 16 July 2020

\begin{abstract}
Although some plants accumulate excessive metal and can grow without any toxic symptoms, the consumption of these plants by humans can be extremely inconvenient for their health. Increasing doses of $\mathrm{Cd}\left(0,10\right.$, and $\left.20 \mathrm{mg} \mathrm{kg}^{-1} \mathrm{Cd}\right)$ and chicken manure $\left(0,500,1000\right.$, and $\left.2000 \mathrm{~kg} \mathrm{da}^{-1}\right)$ were applied to the soil to evaluate the effects of cadmium and chicken manure on growth of spinach (Spinach oleracea L.) leaves and roots and on some heavy metal concentrations. Cadmium decreased the dry weight amounts of spinach both in leaves and in roots, decreased the amounts of $\mathrm{Cd}$ and also other heavy metals. The highest cadmium concentrations were determined at the second dose as $75.04 \mathrm{mg} \mathrm{kg}^{-1}$ in leaves, and $162.17 \mathrm{mg} \mathrm{kg}^{-1}$ in roots. Improved dry weight and decreased $\mathrm{Cr}, \mathrm{Pb}$, and $\mathrm{Fe}$ amounts were determined with chicken manure application. However it was not found proficient to decrease $\mathrm{Cd}$ which was found over the limits of WHO. Because of being highly toxic to humans, health-related limits of cadmium in soils, and in plants consumed by humans have to be carefully controlled in such conditions and the threshold limits must be changed.
\end{abstract}

Keywords: antagonism, dry weight, health, heavy metals, toxicity

\section{Introduction}

Heavy metals; expressed as natural elements with a density greater than $5 \mathrm{~g} \mathrm{~cm}^{-3}$ and an atomic number greater than $20[1,2]$. Heavy metals as the natural components of rocks which comprise various proportions and forms spread to the environment generally from water, air and soil. Some heavy metal trace elements such as copper $(\mathrm{Cu})$, zinc $(\mathrm{Zn})$, iron $(\mathrm{Fe})$,

*e-mail: hcelik@uludag.edu.tr manganese (Mn), molybdenum (Mo), nickel (Ni), cobalt (Co); are absolutely necessary for the plants to carry out their growth, development and physiological life functions effectively. However, it has been reported that excessive doses of these elements, and trace amounts of many heavy metals other than this group, including arsenic (As), mercury (Hg), cadmium (Cd) and lead $\mathrm{Pb})$ may be toxic to plants [3-5].

In parallel with the increase in the human population and the development of today's technology, the natural distribution pattern and concentrations of heavy metals are significantly increased due to the 
industrial activities such as energy and fuel production, radioactive wastes, mining, sludge applications. Nowadays, anthropogenic activities such as excessive usage of fertilizers and pesticides, and irrigation with wastewater were added in to the list [6]. It is reported that the metal concentration in the soil varies between 1 and $100,000 \mathrm{mg} \mathrm{kg}^{-1}$, and high heavy metal levels cause degradation in ecological balance by causing a decrease in soil, product, yield and quality [7-9]. It has been stated that the presence of heavy metals in plants at toxic levels causes deterioration of many physiological events such as transpiration, stoma movements, water intake, photosynthesis, enzyme activity, germination, protein synthesis, membrane stability, hormonal balance [10]. In addition to the deterioration in plants, due to the accumulation of heavy metals in the bodies of humans and other creatures fed with these plants over time; it is reported that it causes serious damage to the human body and can negatively affect their lives $[5,8,9,11]$.

Of the related heavy metals, $\mathrm{Cd}$ has the potential to accumulate in soils, especially as a result of intensive and continuous use of phosphorus fertilizers. And has been indicated that the maximum allowable $\mathrm{Cd}$ concentration in agricultural soils in various countries were between $1-20 \mathrm{mg} \mathrm{kg}^{-1}$ [7]. Depending on the high concentrations of cadmium in the soil, there may be also accumulation of cadmium in plants and can negatively affect human health through the food chain [11]. KabataPendias [7] stated that the solubility of the heavy metals depends on some soil factors such as CEC, clay minerals, carbonates and hydrous oxide metals and also their $\mathrm{pH}$ affected amounts and kind of organic matter. It was also reported that some agricultural practices have also been tried to soil preventing the mobilization of trace metals and the uptake of metals by plants may be depressed with materials having a high capacity to bind metals such as phosphorites, zeolites, montmorillonites, humic organic matter. [7, 12]. In various studies, it has been reported that some organic materials applied to the soil reduce the mobility and uptake of heavy metals in the soil [13]. Organic amendments such as animal manure, crop residues and biosolids have been used to immobilize the heavy metals [12]. Chicken manure is also used as an organic fertilizer source due to its high nutrient content, increasing the efficiency, aeration and water holding capacity of the soil [3, 14].

Plants may grow in normal appearance in the soils contaminated with $\mathrm{Cd}$, however its element contents may not be safe for human consumption. Spinach has been used as a test plant in our experiment because of its consumption that has become widespread in recent years, as well as being a vegetable that can significantly affect human health and nutrition due to its hyper accumulator properties. This research was carried out to determine the effects of cadmium and chicken manure applied to the soil on growth of spinach plants and contents of some heavy metals and also to state the concentrations in soil and also in plants were harmful or not for human nutrition.

\section{Materials and Methods}

The soil sample from $0-20 \mathrm{~cm}$ depth was collected from a field located at the Agricultural Research and Application Centre of Bursa Uludag University (39 $35^{\prime}$, $40^{\circ} 40^{\prime}$ and $28^{\circ} 10^{\prime}, 30^{\circ} 00^{\prime}$ ) in Turkey. Some properties of the soil used in the experiment are shown in Table 1. The soil used in the experiment had a clay texture and a $\mathrm{pH}$ of 7.91. Additionally, it had low lime content and Electrical Conductivity (EC). The soil also had adequate concentrations of organic matter and has not a problem dealing with the nutrient elements and heavy metals. (Table 1).

Air-dried soil was passed through $4 \mathrm{~mm}$ sieve and placed into polyethylene covered plastic pots with an amount of $3.5 \mathrm{~kg}$. The experiment was conducted in randomized plots design with three replicates

Table 1. Some Properties of the soil.

\begin{tabular}{|c|c|c|c|}
\hline Properties & Amounts & Properties & Amounts \\
\hline Texture & Clay & Lime, CaCO,$\%$ & 2.68 \\
\hline Sand, $\%$ & 44.76 & Organic matter, $\%$ & 0.092 \\
\hline Silt, $\%$ & 14.00 & Total nitrogen $(\mathrm{N}), \%$ & 14.51 \\
\hline Clay, $\%$ & 41.24 & Available phosphorus $(\mathrm{P}), \mathrm{mg} \mathrm{kg}^{-1}$ & 12.49 \\
\hline $\mathrm{pH}(1: 2.5$ soil:water) & 7.91 & Iron $(\mathrm{Fe}) \mathrm{mg} \mathrm{kg}^{-1}$ & 1.56 \\
\hline $\mathrm{EC}, \mu \mathrm{S} \mathrm{cm}{ }^{-1}$ & 530.0 & Cupper $(\mathrm{Cu}) \mathrm{mg} \mathrm{kg}^{-1}$ & 0.95 \\
\hline Sodium $(\mathrm{Na}) \mathrm{mg} \mathrm{kg}^{-1}$ & 175.6 & Zinc $(\mathrm{Zn}) \mathrm{mg} \mathrm{kg}^{-1}$ & 31.64 \\
\hline Potassium $(\mathrm{K}) \mathrm{mg} \mathrm{kg}^{-1}$ & 375.5 & Manganese $(\mathrm{Mn}) \mathrm{mg} \mathrm{kg}^{-1}$ & 0.02 \\
\hline Calcium $(\mathrm{Ca}) \mathrm{mg} \mathrm{kg}^{-1}$ & 10048 & Cadmium $(\mathrm{Cd}) \mathrm{mg} \mathrm{kg}^{-1}$ & 1.82 \\
\hline Magnesium $(\mathrm{Mg}) \mathrm{mg} \mathrm{kg}^{-1}$ & 390.2 & Lead $(\mathrm{Pb}) \mathrm{mg} \mathrm{kg}{ }^{-1}$ & 0.02 \\
\hline Boron $(\mathrm{B}) \mathrm{mg} \mathrm{kg}{ }^{-1}$ & 0.65 & Chromium $(\mathrm{Cr}) \mathrm{mg} \mathrm{kg}^{-1}$ & \\
\hline
\end{tabular}


Table 2. Some properties of the chicken manure* used in the trial.

\begin{tabular}{|c|c|c|c|}
\hline Properties & Amounts & Properties & Amounts \\
\hline $\mathrm{pH}(1: 2.5 \mathrm{w} / \mathrm{v})$ & 9.82 & Iron $(\mathrm{Fe}) \mathrm{g} \mathrm{kg}^{-1}$ & 6.84 \\
\hline $\mathrm{EC} \mu \mathrm{S} \mathrm{cm}^{-1}$ & 11.72 & Cupper $(\mathrm{Cu}) \mathrm{mg} \mathrm{kg}^{-1}$ & 37.41 \\
\hline Organic matter \% & 42.45 & Zinc $(\mathrm{Zn}) \mathrm{mg} \mathrm{kg}^{-1}$ & 642.75 \\
\hline Nitrogen $(\mathrm{N}) \mathrm{g} \mathrm{kg}^{-1}$ & 13.89 & Manganese $(\mathrm{Mn}) \mathrm{mg} \mathrm{kg}^{-1}$ & 44.48 \\
\hline Phosphorus $(\mathrm{P}) \mathrm{g} \mathrm{kg}^{-1}$ & 16.13 & Boron $(\mathrm{B}) \mathrm{mg} \mathrm{kg}^{-1}$ & 0.22 \\
\hline Sodium $(\mathrm{Na}) \mathrm{g} \mathrm{kg}^{-1}$ & 4.55 & Cadmium $(\mathrm{Cd}) \mathrm{mg} \mathrm{kg}^{-1}$ & 0.21 \\
\hline Potassium $(\mathrm{K}) \mathrm{g} \mathrm{kg}^{-1}$ & 23.35 & Chromium $(\mathrm{Cr}) \mathrm{mg} \mathrm{kg} \mathrm{kg}^{-1}$ & 54.00 \\
\hline Calcium $(\mathrm{Ca}) \mathrm{g} \mathrm{kg}^{-1}$ & 60.73 & & \\
\hline Magnesium $(\mathrm{Mg}) \mathrm{g} \mathrm{kg}^{-1}$ & 7.49 & & \\
\hline
\end{tabular}

*Trade name Batısel which is the commercial product of Yükseller company, Manisa/Turkey.

in greenhouse conditions. Three different rates of cadmium $\left(0,10\right.$ and $\left.20 \mathrm{mg} \mathrm{kg}{ }^{-1} \mathrm{Cd}\right)$ as cadmium sulphate $\left(3 \mathrm{CdSO}_{4} .8 \mathrm{H}_{2} \mathrm{O}\right)$ (Extra pure, Merck, Germany) in the form of solution, and increasing doses of chicken manure $\left(0,500,1000\right.$ and $\left.2000 \mathrm{~kg} \mathrm{da}^{-1}\right)$ were applied to the pots in a solid state. The chicken manure used in the experiment is a product of Yükseller company, Manisa/Turkey which is sold as pelleted and under the trade name Batisel. Some properties of the chicken manure were analysed before the experiment and the results were shown on Table 2. Before planting $50 \mathrm{mg} \mathrm{kg}^{-1} \mathrm{~N}, 40 \mathrm{mg} \mathrm{kg}^{-1} \mathrm{P}$, and $50 \mathrm{mg} \mathrm{kg}^{-1} \mathrm{~K}$ were also added to the pots using ammonium nitrate $\left(\mathrm{NH}_{4} \mathrm{NO}_{3}\right)$ (Extra pure, Merck, Germany) and monopotassium phosphate $\left(\mathrm{KH}_{2} \mathrm{PO}_{4}\right)$ (Emprove, Merck, Germany) and the pots were incubated for 60 days.

Five spinach (spinach oleracea L.) seed cultivars 'Reis F1' were planted in each pot, which were $20 \mathrm{~cm}$ in diameter and $18 \mathrm{~cm}$ deep, and later on thinningout was done after germination and three plants were left. The water content of the pots was adjusted to $70 \%$ of the field capacity during the experiment. After 45 days, the spinach leaves were cut over the soil level and then the leaves and the spinach roots also removed and were immediately transferred to the laboratory. In order to avoid possible contamination from dust, the samples were washed once in tap water and twice with deionized water. The samples were dried at $70^{\circ} \mathrm{C}$ for $72 \mathrm{~h}$ in a hot air oven (Nuve KD 400, Turkey), weighed and then ground from $0.5 \mathrm{~mm}$ sieve using a laboratory mill (Foss CT 193 cyclotec, Denmark).

For the determination of the nutrient concentrations in leaves and roots, the ground samples were digested using a mixture of $3 \mathrm{~mL}$ of nitric acid $\left(\mathrm{HNO}_{3}\right)(65 \%$, Emplura, Merck) and $3 \mathrm{~mL}$ of hydrogen peroxide $\left(\mathrm{H}_{2} \mathrm{O}_{2}\right)$ (35\%, Emprove, Merck, Germany) in a microwave oven (Berghof MWS 2, Germany) [15]. Heavy metals $(\mathrm{Cd}, \mathrm{Pb}$ and $\mathrm{Cr}$ ), and the nutrients $(\mathrm{Fe}, \mathrm{Zn}, \mathrm{Mn}$, and $\mathrm{Cu}$ ) amounts were determined by inductively coupled plasma-optical emission spectrometry (ICP-OES)
(Perkin Elmer Optima 2100DV, USA) [16]. The uptaken amounts were calculated using concentration and dry weight values. Data from all of the experiments were subjected to statistical analysis and the mean values were compared using the least significant difference (LSD) multiple range test with the computer program MINITAB 17.1.0.0 (Minitab Inc., State College, Pennsylvania, USA).

\section{Results and Discussion}

\section{Effects of Cadmium on Dry Weight Amounts}

Increasing doses of cadmium applied to the soil significantly affected the leaf and root dry weight yield of spinach plants $(p<0.01)$. With increasing cadmium doses, the leaf and root dry weight yield of the plant was negatively affected, and the lowest leaf (2.77 $\left.\mathrm{g} \mathrm{pot}^{-1}\right)$ and root $\left(0.52 \mathrm{~g} \mathrm{pot}^{-1}\right)$ dry weight yield was obtained from the highest dose of cadmium $(\mathrm{Cd} 2)$ (Table 3). Significant decreases on the growth of spinach plants due to high concentrations of cadmium in our research findings have been supported with the findings of the previous studies done with various leafy vegetables. Chetan and Ami [17] reported decreases on growth parameters of spinach plant grown under two doses of $\mathrm{Cd}$ as compared to control. Canal and Bozkurt [18] reported decreases on plant height, plant weight, and number of leaves of lettuce grown under toxic $\mathrm{Cd}$ conditions. Monteiro et al. [19] also reported a reduction in growth and biomass production in lettuce. Anwar et al. [20] reported reduced biomass at leafy vegetables such as mint, coriander and fenugreek with the application of sewage water containing high amounts of Cd. Decreased dry matter yield as mentioned in the previous trial results, in our experiment is thought to be caused by the deterioration in the uptake of plant nutrients in the presence of $\mathrm{Cd}$ and their function within the plant [21]. 
Table 3. Effects of increasing doses of cadmium and chicken manure on dry weight of leaf and root of spinach.

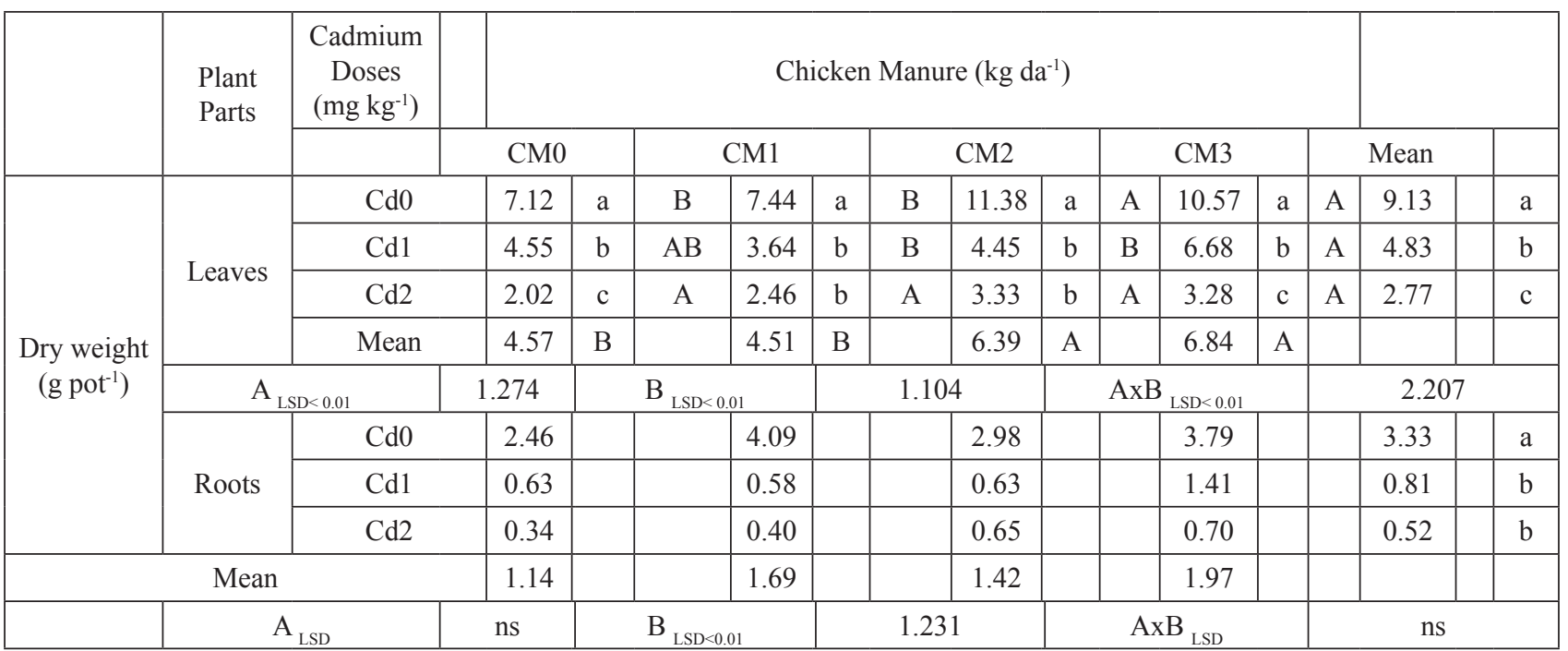

The differences between values by different letters are significant. Capital letters for each row and small letters for each column. ns: not significant

\section{Effects of Cadmium on Cadmium Amounts}

With the applied cadmium doses statistically significant increases $(p<0.01)$ were found on the cadmium concentrations and on the up-taken $\mathrm{Cd}$ amounts in the leaves and in the roots of the spinach plant. The average $\mathrm{Cd}$ concentration of the plants in the applications without cadmium $(\mathrm{Cd} 0)$ was determined as $0.58 \mathrm{mg} \mathrm{kg} \mathrm{m}^{-1}$ in leaves and $1.23 \mathrm{mg} \mathrm{kg}^{-1}$ in roots (Fig. 1). These values increased with cadmium applications and were found as $65.71 \mathrm{mg} \mathrm{kg}^{-1}$ and $75.04 \mathrm{mg} \mathrm{kg}^{-1}$ in leaves, and values in the roots increased more than in the leaves and were found as $108.10 \mathrm{mg} \mathrm{kg}^{-1}$ and $162.17 \mathrm{mg} \mathrm{kg}^{-1}$ respectively. It was observed that cadmium accumulated in the roots, and cadmium concentration was found higher in the roots than leaves (Fig. 1). The results showed the ability of spinach to accumulate the cadmium element in high amounts. Elevated plant $\mathrm{Cd}$ concentrations parallel with increased $\mathrm{Cd}$ doses were also reported in some studies $[22,23]$. Various researches indicated the sufficiency level of $\mathrm{Cd}$ in mature leaf tissues as $0.05-0.2 \mathrm{mg} \mathrm{kg}^{-1}$, $0.013-0.22 \mathrm{mg} \mathrm{kg}^{-1}$ for cereal grains, $0.07-0.28 \mathrm{mg} \mathrm{kg}^{-1}$ for grasses and legumes and excessive or toxic range as $5-30 \mathrm{mg} \mathrm{kg}^{-1}$ and tolerable limit for agronomic crops as $0.05-0.5 \mathrm{mg} \mathrm{kg}^{-1}[7,10]$. The permissible $\mathrm{Cd}$ level in plants was limited as $0.02 \mathrm{mg} \mathrm{kg}^{-1}$ by World Health Organization (WHO) [12]. It was also pointed out that the daily intake of $\mathrm{Cd}$ was limited as $1 \mu \mathrm{g} \mathrm{Cd}$ per $\mathrm{kg}^{-1}$ of the body weight and equivalent to $70 \mu \mathrm{g}$ for a body weight of $70 \mathrm{~kg}^{-1}$ according to WHO reports [24]. The toxic effects of $\mathrm{Cd}$ can be observed in people who regularly consume plants which contain $\mathrm{Cd}$ more than $3 \mathrm{mg} \mathrm{kg}^{-1}$ in their tissues [25]. In our research, while the spinach plants which were grown under normal soil conditions had suitable $\mathrm{Cd}$ concentrations in their leaves, it was determined that the leaves grown under $\mathrm{Cd}$ applied soils had the $\mathrm{Cd}$ concentrations over this dedicated limits. Once $\mathrm{Cd}$ is absorbed by this edible plant parts it causes disorders in kidneys and bones, damages in reproductive, nervous and cardiovascular systems and also leads to cancer [26-28]. So regularly consumption of these plants might be dangerous for human health.

Since the accumulation of cadmium in the roots adversely affects root development, and the up-taken amount of cadmium was detected more in the leaves rather than in the roots. The lowest up-taken amount of cadmium in leaves $\left(5.24 \mu \mathrm{g} \mathrm{pot}^{-1}\right)$ and in roots (3.62 $\mu \mathrm{g} \mathrm{pot}^{-1}$ ), were obtained from the control dose (Cd0) where cadmium was not applied (Table 4). The highest up-taken cadmium amount was obtained from the first dose of cadmium (Cd1), in being leaves $\left(314.42 \mu \mathrm{g} \mathrm{pot}^{-1}\right)$ and in the roots $\left(89.36 \mu \mathrm{g} \mathrm{pot}^{-1}\right)$. The amount decreased at the highest dose of $\mathrm{Cd}$ in relation to the decrease in dry weight and found as $209.92 \mu \mathrm{g}$ pot $^{-1}$ in leaves and $84.74 \mu \mathrm{g} \mathrm{pot}^{-1}$ in the roots. These findings were in correspondence with the findings of Dotaniya et al. [29] which reported the Cd uptake of spinach in leaves as 180 and $200 \mu \mathrm{g} \mathrm{pot}^{-1}$ in 1 and $2 \mathrm{mg} \mathrm{kg}{ }^{-1} \mathrm{Cd}$ doses. However the up-taken amounts may show differences due to the soil factors such as $\mathrm{Cd}$ concentration in soil, $\mathrm{pH}$, level of organic matter and also plant species and varieties [10,11].

\section{Effects of Cadmium on Some Other Heavy Metal Amounts}

The effect of increasing cadmium doses applied to the soil, on the concentrations and the up-taken amounts of $\mathrm{Cr}$ with leaves and roots of the spinach plant was found statistically significant $(p<0.01)$. 


\section{Cd Concentrations $\left(\mathrm{mg} \mathrm{kg}^{-1}\right)$}

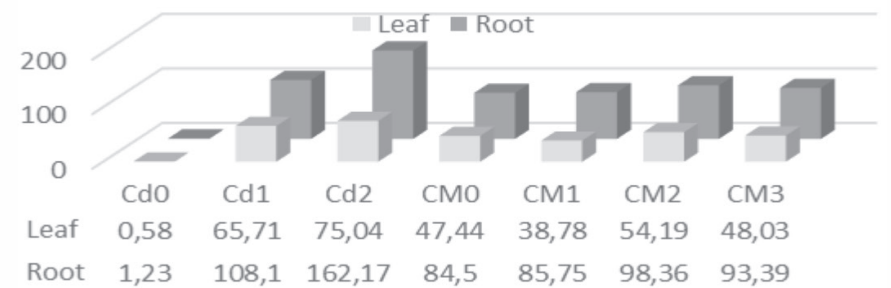

$\mathrm{Pb}$ Concentrations $\left(\mathrm{mg} \mathrm{kg}^{-1}\right)$

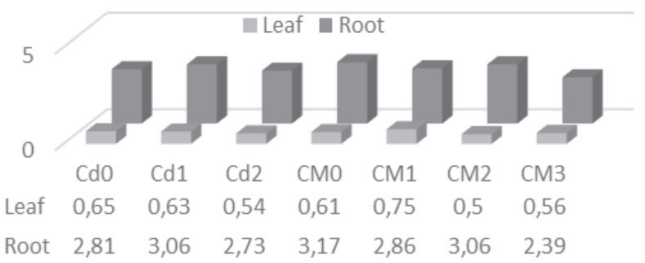

Fe Concentrations $\left(\mathrm{mg} \mathrm{kg}^{-1}\right)$

n Leaf $=$ Root

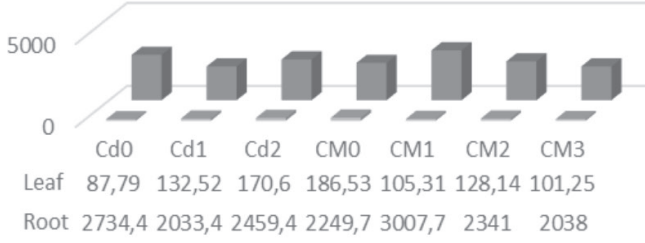

Mn Concentrations $\left(\mathrm{mg} \mathrm{kg}^{-1}\right)$

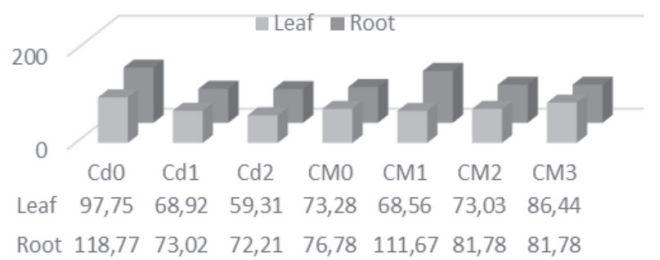

Cr Concentrations $\left(\mathrm{mg} \mathrm{kg}^{-1}\right)$

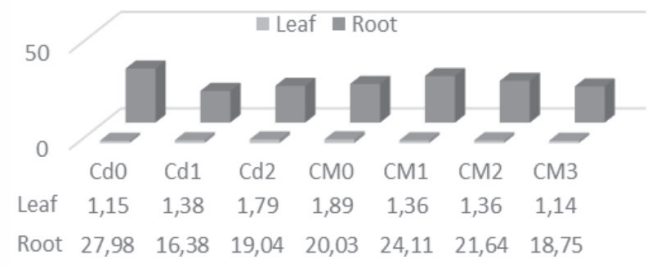

Zn Concentrations $\left(\mathrm{mg} \mathrm{kg}^{-1}\right)$

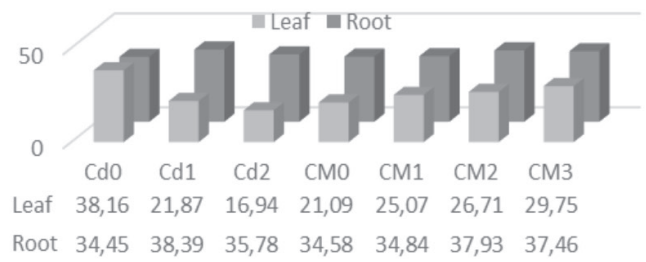

Cu Concentrations $\left(\mathrm{mg} \mathrm{kg}^{-1}\right)$

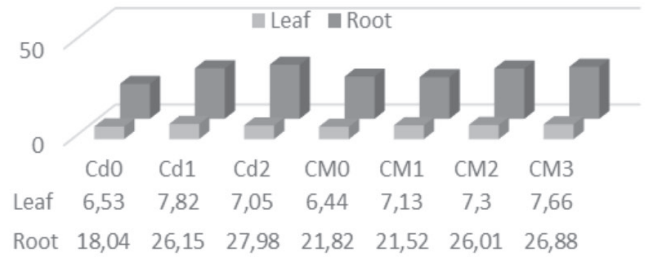

Fig 1. Effects of increasing doses of cadmium and chicken manure on some heavy metal contents of leaf and root of spinach.

Chromium concentrations and the up-taken amounts in the roots were found higher than leaves. Along with the increased cadmium doses, the up-taken amount of $\mathrm{Cr}$ by the leaves and roots of the plant was decreased. While the highest chromium uptake in the leaf $\left(10.23 \mu \mathrm{g} \mathrm{pot}^{-1}\right)$ and in the root $\left(106.43 \mu \mathrm{g}\right.$ pot $\left.^{-1}\right)$, was obtained from the control dose $(\mathrm{Cd} 0)$ where cadmium was not applied, the lowest $\mathrm{Cr}$ amount in the leaves (4.67 $\left.\mu \mathrm{g} \mathrm{pot}^{-1}\right)$ and in the roots $\left(9.52 \mu \mathrm{g}\right.$ pot $\left.^{-1}\right)$ was obtained from the highest dose of cadmium $(\mathrm{Cd} 2)$. While the highest $\mathrm{Cr}$ concentration in the roots $\left(27.98 \mathrm{mg} \mathrm{kg}^{-1}\right)$ was found at the control dose $(\mathrm{Cd} 0)$ and decreased with increasing cadmium doses, owing to the competition of $\mathrm{Cr}$ with $\mathrm{Cd}$ (Fig. 1). The findings of Dotaniya et al. [29] also confirm the competition between $\mathrm{Cd}$ and $\mathrm{Cr}$. In their research results decreased $\mathrm{Cr}$ concentrations and uptake were reported in both roots and in the leaves of spinach and they concluded as a higher $\mathrm{Cd}$ amount had an antagonistic effect over $\mathrm{Cr}$.

The effect of increasing cadmium doses applied to the soil, on the up-taken amounts of $\mathrm{Pb}$ of leaves and roots of the spinach plant was found statistically significant $(\mathrm{p}<0.01)$, The highest up-taken $\mathrm{Pb}$ was obtained in the leaves $\left(5.37 \mu \mathrm{g} \mathrm{pot}^{-1}\right)$ and in the roots $\left(9.28 \mu \mathrm{g} \mathrm{pot}^{-1}\right)$, from the control dose $(\mathrm{Cd} 0)$ where cadmium was not applied (Table 4). Along with the increased cadmium doses, the up-taken amount of $\mathrm{Pb}$ by the plant's leaves and roots decreased, and the lowest up-taken $\mathrm{Pb}$ amount, in leaves $\left(1.42 \mu \mathrm{g} \mathrm{pot}^{-1}\right)$ and in roots $\left(1.30 \mu \mathrm{g} \mathrm{pot}^{-1}\right)$ was obtained from the highest cadmium dose $(\mathrm{Cd} 2)$. Lead also accumulated in the roots. Even though there was inhibited root development due, the excessive concentration in the roots, the uptaken amount of $\mathrm{Pb}$ at the $\mathrm{Cd}$ applied pots, was found more in the leaves rather than in the roots. Similar to the negative effect of $\mathrm{Cd}$ on $\mathrm{Pb}$ uptake in our study, its competition with elements such as $\mathrm{K}, \mathrm{Ca}, \mathrm{Mg}, \mathrm{Fe}, \mathrm{Mn}$, $\mathrm{Cu}, \mathrm{Zn}$ and $\mathrm{Ni}$ was also reported [30].

The effect of increasing cadmium doses applied to the soil on the Fe concentrations of leaves and roots of the spinach plant and their up-taken amounts was found statistically significant $(\mathrm{p}<0.01)$. Concentrations of Fe 
Table 4. Effects of increasing doses of cadmium and chicken manure on $\mathrm{Cd}, \mathrm{Cr}$, and $\mathrm{Pb}$ uptake of leaf and root of spinach

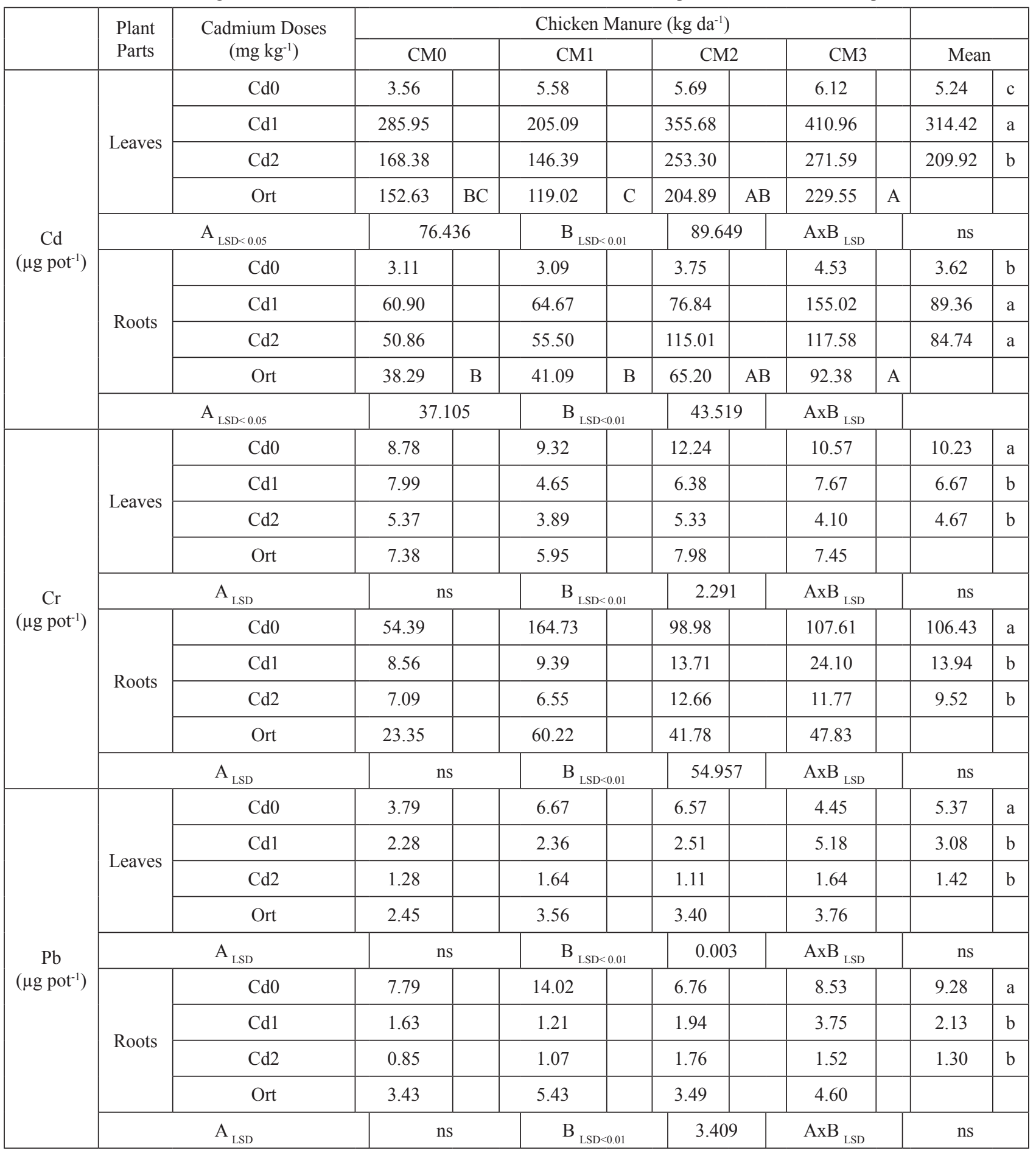

The differences between values by different letters are significant. Capital letters for each row and small letters for each column. ns: not significant

in the leaves increased with the $\mathrm{Cd}$ doses and the highest Fe $\left(170.6 \mathrm{mg} \mathrm{kg}^{-1}\right)$ was found in $\mathrm{Cd} 2$. However, in the roots $\left(2734.44 \mathrm{mg} \mathrm{kg}^{-1}\right)$ the highest $\mathrm{Fe}$ was observed in $\mathrm{Cd} 0$, because of the competition with $\mathrm{Cd}$, the amounts of Fe decreased with $\mathrm{Cd}$ doses (Fig. 1). Low concentrations of iron in $\mathrm{Cd} 0$ in the leaves, were dedicated to the result of dilution effect. The antagonistic relationships between $\mathrm{Cd}$ and $\mathrm{Fe}$ uptake as well as the effects of
Fe on the uptake of Cd by the plant and transport from the roots to the shoots are also important. Several studies on cadmium stress showed impaired $\mathrm{Fe}$ translocation from roots to shoots and also decreased concentrations in the plant with $\mathrm{Cd}$ application [21, 31, 32]. Along with the increased cadmium doses, the up-taken amount of iron by the leaves and roots of the plant decreased. While the highest iron uptake in the leaf 
(770.90 $\left.\mu \mathrm{g} \mathrm{pot}^{-1}\right)$ and in the root $\left(10323.0 \mu \mathrm{g} \mathrm{pot}^{-1}\right)$, was obtained from the control dose $(\mathrm{Cd} 0)$ where cadmium was not applied, the lowest iron up take in the leaves $\left(424.53 \mu \mathrm{g} \mathrm{pot}^{-1}\right)$ and in the roots $\left(1288.7 \mu \mathrm{g} \mathrm{pot}^{-1}\right)$ was obtained from the highest dose of cadmium $(\mathrm{Cd} 2)$ (Table 5). Although the accumulation of cadmium in the roots affected the root development more than leaves, and over accumulation of iron in the roots caused the up-taken amount of iron to be found higher in the roots compared to the leaves.
The effect of increasing cadmium doses applied to the soil, on the up-taken amounts of $\mathrm{Zn}$ of leaves and roots of the spinach plant was found statistically significant $(p<0.01)$, however the effect, was not significant on the concentrations of the roots. Along with the increased cadmium doses the up-taken amount of $\mathrm{Zn}$ by the plant's leaves and roots decreased suggesting the $\mathrm{Cd} / \mathrm{Zn}$ antagonism [10, 21, 33]. The highest up-taken $\mathrm{Zn}$ was obtained in the leaves $\left(327.35 \mu \mathrm{g} \mathrm{pot}^{-1}\right)$ and in the roots $\left(112.12 \mu \mathrm{g} \mathrm{pot}^{-1}\right)$, from the

Table 5. Effects of increasing doses of cadmium and chicken manure on $\mathrm{Fe}, \mathrm{Zn}, \mathrm{Mn}$, and $\mathrm{Cu}$ uptake of leaf and root of spinach

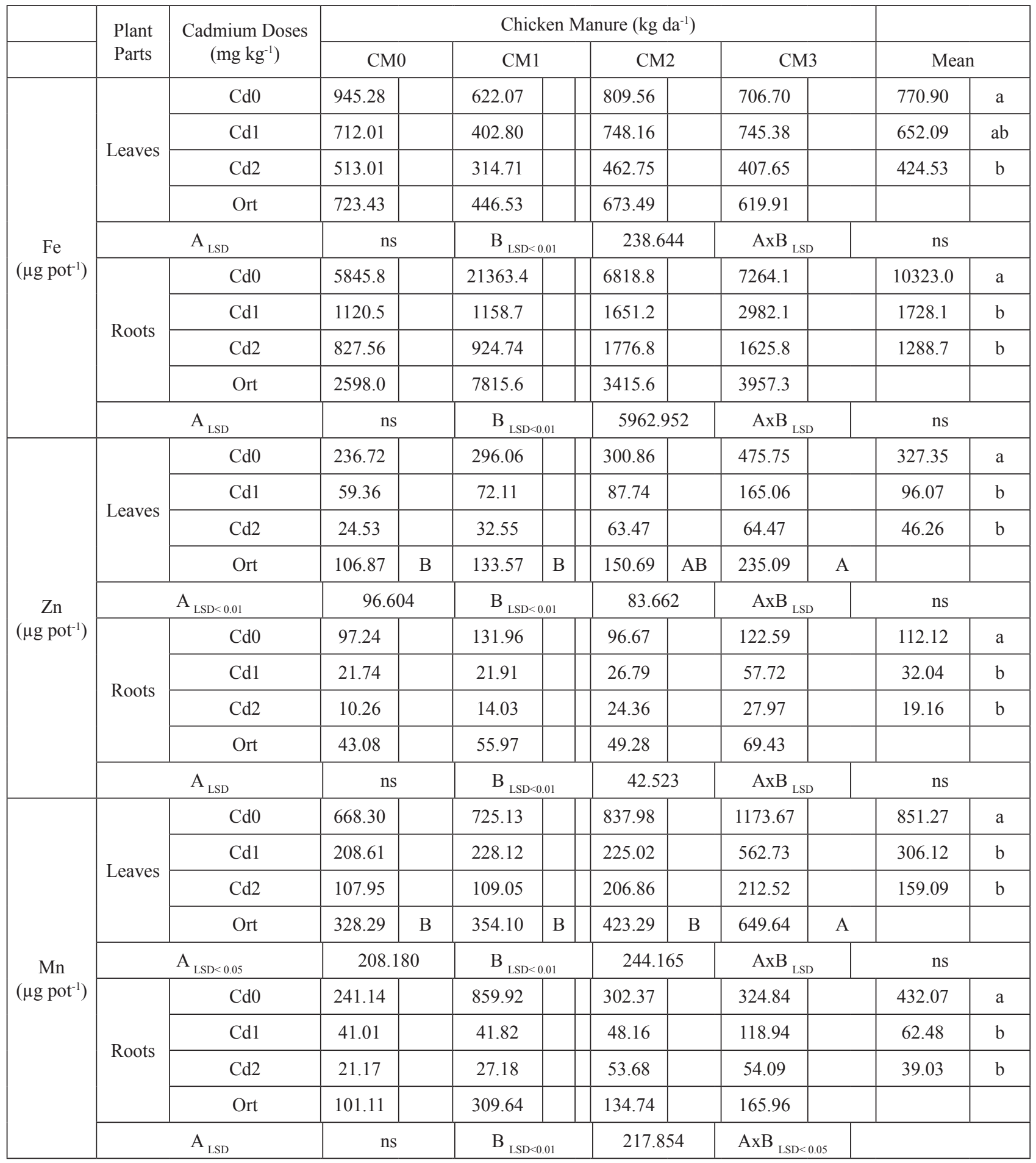


Table 5. Continued.

\begin{tabular}{|c|c|c|c|c|c|c|c|c|c|c|c|c|}
\hline \multirow{10}{*}{ 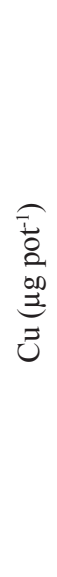 } & \multirow{4}{*}{ Leaves } & $\mathrm{Cd} 0$ & 42.62 & & 49.41 & & 51.96 & & 75.18 & & 54.79 & $\mathrm{a}$ \\
\hline & & $\mathrm{Cd} 1$ & 25.83 & & 28.60 & & 29.44 & & 53.22 & & 34.27 & b \\
\hline & & $\mathrm{Cd} 2$ & 10.14 & & 14.74 & & 26.32 & & 25.90 & & 19.27 & b \\
\hline & & Ort & 26.20 & B & 30.92 & B & 35.91 & $\mathrm{AB}$ & 51.43 & A & & \\
\hline & \multicolumn{2}{|c|}{$\mathrm{A}_{\mathrm{LSD}<0.01}$} & \multicolumn{2}{|c|}{19.419} & \multicolumn{2}{|c|}{$\mathrm{B}_{\mathrm{LSD}<0.01}$} & \multicolumn{2}{|c|}{16.818} & \multicolumn{2}{|c|}{$\mathrm{AxB}_{\text {LSD }}$} & \multicolumn{2}{|l|}{ ns } \\
\hline & \multirow{4}{*}{ Roots } & $\mathrm{Cd} 0$ & 49.60 & & 64.37 & & 52.33 & & 68.48 & & 58.70 & $\mathrm{a}$ \\
\hline & & $\mathrm{Cd} 1$ & 14.60 & & 12.61 & & 20.93 & & 41.05 & & 22.29 & $\mathrm{~b}$ \\
\hline & & $\mathrm{Cd} 2$ & 7.94 & & 10.89 & & 19.81 & & 21.88 & & 15.13 & $\mathrm{~b}$ \\
\hline & & Ort & 24.04 & & 29.29 & & 31.02 & & 43.80 & & & \\
\hline & \multicolumn{2}{|c|}{$\mathrm{A}_{\mathrm{LSD}}$} & \multicolumn{2}{|c|}{ ns } & \multicolumn{2}{|c|}{$\mathrm{B}_{\mathrm{LSD}<0.01}$} & \multicolumn{2}{|c|}{22.598} & \multicolumn{2}{|c|}{$\mathrm{AxB}_{\text {LSD }}$} & \multicolumn{2}{|l|}{ ns } \\
\hline
\end{tabular}

The differences between values by different letters are significant. Capital letters for each row and small letters for each column. ns: not significant

control dose (Cd0) where cadmium was not applied, and the lowest up-taken $\mathrm{Zn}$ amount, in leaves $\left(46.26 \mu \mathrm{g} \mathrm{pot}^{-1}\right)$ and roots $\left(19.16 \mu \mathrm{g} \mathrm{pot}^{-1}\right)$ was obtained from the highest cadmium dose (Cd2). Although Zn concentrations were found high in the roots than in leaves, the up-taken $\mathrm{Zn}$ amounts were found high in the leaves because of the inhibited root dry weight and being not too high concentrations of $\mathrm{Zn}$ in the roots as compared with $\mathrm{Fe}$ (Table 5).

The effect of increasing cadmium doses applied to the soil, on the Mn concentrations and on the uptaken amounts of $\mathrm{Mn}$ of leaves and roots of the spinach plant was found statistically significant $(\mathrm{p}<0.01)$. Along with the increased cadmium doses, concentrations and the up-taken amount of Mn by the plant's leaves and roots decreased. The highest up-taken Mn was obtained in the leaves $\left(851.27 \mu \mathrm{g} \mathrm{pot}^{-1}\right)$ and in the roots (432.07 $\left.\mu \mathrm{g} \mathrm{pot}^{-1}\right)$, from the control dose $(\mathrm{Cd} 0)$ where cadmium was not applied, and the lowest up-taken $\mathrm{Mn}$ amount, in leaves (159.09 $\left.\mu \mathrm{g} \mathrm{pot}^{-1}\right)$ and roots $\left(39.03 \mu \mathrm{g} \mathrm{pot}^{-1}\right)$ was obtained from the highest cadmium dose $(\mathrm{Cd} 2)$. Manganese concentrations in the roots were also found higher than in leaves. The highest Mn concentration (118.77 $\left.\mathrm{mg} \mathrm{kg}^{-1}\right)$ was found at the control dose $(\mathrm{Cd} 0)$ and tended to decrease with increasing cadmium doses and least concentration was found at the second dose of $\mathrm{Cd}(\mathrm{Cd} 2)$ (Fig. 1). The results presented show the competition of $\mathrm{Mn}$ with cadmium clearly. Nazar et al. [10] and Rahman et al. [34] also reported the antagonism between $\mathrm{Cd}$ and $\mathrm{Mn}$, related to the shared transporting sites and confirm the findings of us.

The average $\mathrm{Cu}$ concentration of plants in the applications without cadmium $(\mathrm{Cd} 0)$ was determined as $6.53 \mathrm{mg} \mathrm{kg}^{-1}$ in leaves and $18.04 \mathrm{mg} \mathrm{kg}^{-1}$ in roots (Fig. 1). These values increased with cadmium applications and were found as $7.82 \mathrm{mg} \mathrm{kg}^{-1}$ and $7.05 \mathrm{mg} \mathrm{kg}^{-1}$ in leaves, and the values in the roots increased more than in leaves and were found as $26.15 \mathrm{mg} \mathrm{kg}^{-1}$ and $27.98 \mathrm{mg} \mathrm{kg}^{-1}$. It was observed that $\mathrm{Cu}$ also accumulated in the roots, and $\mathrm{Cu}$ concentration was found higher in the roots than leaves (Fig. 1). Since the accumulation of cadmium in the roots adversely affects root development, the up-taken amount of $\mathrm{Cu}$ was detected a little bit more in the leaves rather than in the roots. The highest uptaken amount of $\mathrm{Cu}$ in leaf $\left(54.79 \mu \mathrm{g} \mathrm{pot}^{-1}\right)$ and in root $\left(58.70 \mu \mathrm{g} \mathrm{pot}^{-1}\right)$, were obtained from the control dose (Cd0) where cadmium was not applied (Table 5). The lowest up-taken $\mathrm{Cu}$ amount was obtained from the second dose of cadmium ( $\mathrm{Cd} 2)$, both in leaves $\left(19.27 \mu \mathrm{g} \mathrm{pot}^{-1}\right)$ and in the roots $\left(15.13 \mu \mathrm{g} \mathrm{pot}^{-1}\right)$. Wu and Zhang [35] reported a reduction on $\mathrm{Cu}$ amounts in barley due to the addition of $\mathrm{Cd}$ to the growing medium. Competition of cadmium with the elements $\mathrm{K}, \mathrm{Ca}, \mathrm{Mg}, \mathrm{Fe}, \mathrm{Mn}, \mathrm{Cu}, \mathrm{Zn}$, and $\mathrm{Ni}$ were reported in researches done with different plants [30]. In addition, high cadmium in the plant, along with other microelements, caused chrome and lead amounts to decrease and antagonistic relationship of $\mathrm{Cr}$ and $\mathrm{Pb}$ 's with $\mathrm{Cd}$ has been also revealed in our study. $\mathrm{Cd}$ and not only the nutrients but also the other heavy metals compete for the same transporters, therefore under heavy $\mathrm{Cd}$ toxic conditions the optimization of nutrient elements could prevent the nutrients deficiencies and also reduce the accumulation of $\mathrm{Cd}$ [10].

\section{Effects of Chicken Manure on Dry Weight Amounts}

Increasing doses of chicken manure applied to the soil and its interaction with $\mathrm{Cd}$ have also statistically significant effect $(p<0.01)$ on the dry weight yield of spinach leaves. However, its effect on root dry weights was not found significant. The highest leaf dry weight yield $\left(6.84 \mathrm{~g} \mathrm{pot}^{-1}\right)$ was obtained from the highest application dose of chicken manure (CM3) (Table 3). According to the interactions of cadmium and the chicken manure; the highest leaf dry weight yield 
(11.38 $\left.\mathrm{g} \mathrm{pot}^{-1}\right)$ was obtained from spinach plants in pots (Cd0xCM2), where no cadmium applied and the second dose of chicken manure. In contrast, the lowest leaf dry weight yield (2.02 $\left.\mathrm{g} \mathrm{pot}^{-1}\right)$ was obtained from spinach plants in pots $(\mathrm{Cd} 2 \mathrm{xCM} 0)$, where no chicken manure was applied and the highest level of cadmium. Chicken manure is a good source of nutrient elements and serves as a soil amendment material improving soil physical, chemical and also the biological properties [36]. Humic substances in chicken manure exhibit behaviours similar to growth hormones in plants, increase the intake of plant nutrients, promote plant growth and have a positive effect on increasing the amount of dry matter $[3,12,14]$. Humic compounds may be an important alternative in terms of increasing nutrient availability and regulating the toxicity problems in some areas. It has been stated that humic acids are effective on plant growth and development, and when applied in small quantities, it positively affects the development of plants. However, when applied in large quantities, ineffective or even quite negative effects on development were also reported [37].

\section{Effects of Chicken Manure on Cd Amounts}

The effect of increasing doses of chicken manure applied to the soil on the up-taken amount of cadmium of the leaves and roots of the spinach plant was found statistically significant $(p<0.05)$. In parallel with the increasing chicken manure applications, concentrations and the up-taken amount of cadmium by the plant has increased (Fig. 1 and Table 4). The highest cadmium up take was obtained from the highest application dose of chicken manure (CM3) in the leaf (229.55 $\left.\mu \mathrm{g} \mathrm{pot}^{-1}\right)$ and in the root $\left(92.38 \mu \mathrm{g} \mathrm{pot}^{-1}\right)$ (Table 4). Stimulating effect of humic substances on plant growth is associated with increasing the intake of macro nutrients. In addition to macro and micro plant nutrients, poultry manure can also contain many heavy metals depending on the production and management process of the poultry and the amount of $\mathrm{As}, \mathrm{Cd}, \mathrm{Cu}$ and $\mathrm{Mn}$ of the soils may increase compared to the control with chicken manure applications [38]. It has been reported that some organic materials applied to the soil reduce the mobility and uptake of heavy metals in the soil by increasing the surface charge and supplies the retention of $\mathrm{Cd}$ in the soil [12]. The ability of soils to absorb these trace elements depends on their ability to form $\mathrm{pH}$-dependent surface loads of organic matter, cation exchange capacities, clay minerals and hydrated iron and manganese oxides [39, 40, 41]. Organic amendments including humic substances, increase the surface charge and can form complexes with metal cations, and organic bond fractions and therefore increase intake or, conversely compete with roots and reduce the uptake $[12,28]$.

\author{
Effects of Chicken Manure \\ on Some Heavy Metal Amounts
}

The effect of increasing doses of chicken manure applied to the soil, on the $\mathrm{Cr}, \mathrm{Pb}$ and $\mathrm{Fe}$ uptake of the leaves and the roots of the spinach plant was not statistically significant. In contrast, it was found significant on the concentration of $\mathrm{Cr}$ in the leaves (Data not shown). Although the highest $\mathrm{Cr}$ concentration was found $\left(1.89 \mathrm{mg} \mathrm{kg}^{-1}\right.$ ) at control pots (CM0) tended to decrease with the increasing chicken manure and was found least (1.14 $\mathrm{mg} \mathrm{kg}^{-1}$ ) at the highest dose (CM3) (Fig. 1). The effect of increasing doses of chicken manure applied to the soil, on the concentrations of $\mathrm{Pb}$ of the leaves and the roots of the spinach plant was not found statistically significant. However, the concentrations of $\mathrm{Fe}$ were found significant both in leaves and roots. The highest Fe concentration was found $\left(185.53 \mathrm{mg} \mathrm{kg}^{-1}\right)$ in control pots (CM0) tended to decrease with the increasing chicken manure and found least in leaves $\left(101.25 \mathrm{mg} \mathrm{kg}^{-1}\right)$, and in roots (2038 $\mathrm{mg} \mathrm{kg}^{-1}$ ) at the highest dose (CM3) (Fig. 1).

The effect of increasing doses of chicken manure applied to the soil on the up-taken amount of $\mathrm{Zn}, \mathrm{Mn}$, and $\mathrm{Cu}$ in the leaves of the spinach plant was found statistically significant $(\mathrm{p}<0.05)$ but not significant in the roots. In parallel with the increasing chicken manure applications, the amount of up-taken $\mathrm{Zn}$, $\mathrm{Mn}$, and $\mathrm{Cu}$ by the plant has increased. The highest up-taken amounts were obtained from the highest application dose of chicken manure (CM3) in the leaves as $\left(235.09 \mu \mathrm{g}\right.$ pot $\left.^{-1}\right),\left(649.64 \mu \mathrm{g}\right.$ pot $\left.^{-1}\right)$, and (51.43 $\mu \mathrm{g} \mathrm{pot}^{-1}$ ) respectively (Table 4). Rhizosphere is an important environment on building the relations between nutrients, heavy metals and roots. Nutrient elements and metals may precipitate, absorb or form complexes with organic compounds depending to the rhizosphere $\mathrm{pH}$, redox potential and chelating capacity. The solubility and availability of the $\mathrm{Cd}$ and other heavy metals could be reduced if they bound in to chelate complex [10]. Interaction between metal and solid phase of humic acid may decrease availability of heavy metals and various research results were reported dealing with the decreased heavy metal uptake by plants with the applications of organic amendments [13]. Kamari et al [42] also reported the immobilization of heavy metals in soil with manure applications in some studies and depended on the effectiveness of stabilization to the nature of contaminants, physical and chemical characteristics of the amendment and also the type of soil. On the other hand formation of organa-metal compounds may increase the solubility of heavy metal and availability in plants [37]. Parallel to the findings of us, Arroyo et al. [43] also pointed increased concentrations of $\mathrm{Cu}$ in plants grown on the poultry manure amended soils. 


\section{Conclusions}

Cadmium concentrations and the up-taken amounts increased with the addition of $\mathrm{Cd}$ to soil. This situation led degradation on the dry weight of spinach both in leaves and in roots and also decreased the amounts of other heavy metals. $\mathrm{Cd}$ and also $\mathrm{Pb}, \mathrm{Cr}, \mathrm{Zn}, \mathrm{Fe}$, $\mathrm{Mn}$ and $\mathrm{Cu}$ were accumulated in spinach roots rather than leaves. Adding chicken manure to the soil under toxic conditions of $\mathrm{Cd}$ improved the dry weight of the plants, and lessens the amounts of $\mathrm{Cr}, \mathrm{Pb}$, and $\mathrm{Fe}$ but not found proficient to decrease $\mathrm{Cd}, \mathrm{Zn}, \mathrm{Mn}$, and $\mathrm{Cu}$ amounts. High amounts of $\mathrm{Cd}$ in the soil was not only accumulated $\mathrm{Cd}$ in spinach roots, but also raised the amounts in the leaves. However, no visual chlorotic or necrotic deformation and toxicity symptoms were found because of its tolerance to toxicity. The tolerance and normal appearance of the plants to elevated concentrations of trace metals in soils may result a health risk to humans and also to animals which consumes these plants. Because of the $\mathrm{Cd}$ amounts found over the limits of $\mathrm{WHO}$, consumption of these spinach plants by humans were found dangerous for their health. In case of trace elements like $\mathrm{Cd}$ that are easily tolerated by plants such as spinach and highly toxic to humans, health-related limits of these elements in soils, and in plants consumed by humans have to be carefully controlled and the threshold limits must be changed.

\section{Acknowledgements}

This manuscript was prepared with some components of the MSc. thesis.

\section{Conflict of Interest}

The authors declare no conflict of interest.

\section{References}

1. QADIR S., JAMSHIEED S., RASOOL S., ASHRAF M., AKRAM N.A., AHMAD P. Modulation of plant growth and metabolism in cadmium-enriched environments. Reviews of Environmental Contamination and Toxicology, 229, 51, 2014.

2. ALI H., KHAN E. What are heavy metals? Longstanding controversy over the scientific use of the term 'heavy metals' - proposal of a comprehensive definition. Toxicological and Environmental Chemistry, 100 (1), 6, 2018.

3. ADESOYE A.M., ADEKOLA F.A., OLUKOMAIYA K.O., OLUKOMAIYA O.O., IWUCHUKWU P.O. Evaluation of physical properties and heavy metal composition of manure of some domestic animals. International Journal of Innovation and Scientific Research, 9 (2), 293, 2014.

4. ZHANG X., GAO B., XIA H. Effect of cadmium on growth, photosynthesis, mineral nutrition and metal accumulation of bana grass and vetiver grass. Ecotoxicology and Environmental Safety, 106, 102, 2014.

5. ALI A.S.M., AHMED H.A.M., EMARA H.A.E.A., JANJUA M.N., ALHAFEZ N. Estimation and BioAvailability of Toxic Metals between Soils and Plants. Polish Journal of Environmental Studies, 28 (1), 15, 2019.

6. DORAK S., ÇELIK H. Seasonal Variation of Some Trace Element and Heavy Metal Concentrations in a Turkish Stream. Polish Journal of Environmental Studies, 29 (1), 589, 2020.

7. KABATA-PENDIAS A. Trace Elements in Soils and Plants. 4th Ed.; CRC Press, Boca Raton, FL., USA. 520, 2011.

8. SHAHEEN N., IRFAN N.M., KHAN I.N., ISLAM S., ISLAM M.S., AHMED M.K. Presence of heavy metals in fruits and vegetables: Health risk implications in Bangladesh. Chemosphere, 152, 431, 2016.

9. ANTONIADIS V., SHAHEEN S.M., LEVIZOU E., SHAHID M., NIAZI N.K., VITHANAGE M., OK Y.S., BOLAN, N., RINKLEBE J. A critical prospective analysis of the potential toxicity of trace element regulation limits in soils worldwide: Are they protective concerning health risk assessment? - A review. Environment International, 127, 819, 2019.

10. NAZAR R., IQBAL N., MASOOD A., KHAN M.I.R., SYEED S., KHAN N.A. Cadmium toxicity in plants and role of mineral nutrients in its alleviation. 2012.

11. CHEN L., CUI Z.X., WANG D. Variations in Cd and $\mathrm{Pb}$ Accumulations of Hot Pepper (Capsicum annuum L.) Cultivars for Screening Pollution-and Nitrate-Safe Cultivars. Polish Journal of Environmental Studies, 29 (4), 2020.

12. HINA K., KANWAL S.S., ARSHAD M., GUL I. Effect of cadmium $(\mathrm{Cd})$ stress on spinach (Spinacea oleracea) and its retention kinetics in soil in response to organic amendments. Pakistan Journal of Agricultural Sciences, 56 (1), 179, 2019.

13. CANAL S.B., BOZKURT M.A., KIPCAK S. The effects of organic amendments on cadmium uptake of spinach (Spinacia oleracea L.) and plant growth under cadmium toxicity. Fresenius Environmental Bulletin, 27 (5), 3174, 2018.

14. DIKINYA O., MUFWANZALA N. Chicken manureenhanced soil fertility and productivity: effects of application rates. Journal of Soil Science and Environmental Management. 1, 46, 2010.

15. ÇELIK H., TURAN M.A., AŞIK B.B., KATKAT A.V. Evaluation of analytical methods for boron determination in maize shoots. Communications in Soil Science and Plant Analysis, 48 (21), 2573, 2017.

16. HANSEN T.H., BANG T.C. DE., LAURSEN K.H., PEDAS P., HUSTED S, SCHJORRING J.K. Multi element plant tissue analysis using ICP spectrometry, In: Plant Mineral Nutrients. Methods in Molecular Biology (Methods and Protocols), Maathuis, F.J.; Humana Press, Totowa, NJ. 953. $121,2013$.

17. CHETAN A., AMI P. Effects of heavy metals $(\mathrm{Cu}$ and Cd) on growth of leafy vegetables - Spinacia oleracea and Amaranthus caudatus. International Research Journal of Environment Sciences, 4, 6), 63, 2015.

18. CANAL S.B., BOZKURT M.A. Kadmiyum toksisitesine karşı demir gübrelemesi ve arıtma çamurunun marul (Lactuca Sativa L. Var. Longifolia) bitkisinin gelişimine ve antioksidatif enzim aktivitesine etkisi. Yüzüncü Y1l Üniversitesi Tarım Bilimleri Dergisi, 28 (1), 19, 2018 [In Turkish]. 
19. MONTEIRO M.S., SANTOS C., SOARES A.M.V.M., MANN R.M. Assessment of biomarkers of cadmium stress in lettuce. Ecotoxicology and Environmental safety, 72 (3), 811, 2009.

20. ANWAR S., NAWAZ M.F., GUL S., RIZWAN M., ALI S., KAREEM A. Uptake and distribution of minerals and heavy metals in commonly grown leafy vegetable species irrigated with sewage water. Environmental monitoring and assessment, 188 (9), 541, 2016.

21. QIN SHIYU, HONGEN L.I.U., ZHAOJUN N.I.E., RENGEL Z., WEI G.A.O., CHANG L.I., PENG, Z.H.A.O. Toxicity of cadmium and its competition with mineral nutrients for uptake by plants: A review. Pedosphere, 30 (2), 168, 2020.

22. LI S., WANG F., RU M., NI W. Cadmium Tolerance and Accumulation of Elsholtzia Argyi Oritgining from a Zinc/Lead Mining Site - a Hydroponics Experiment. International Journal of Phytoremediation, 16, 1257, 2014.

23. BAKHSHAYESH B.E., DELKASH M., SCHOLZ M. Response of Vegetables to Cadmium Enriched-Soil. Water, 6 (5), 1246, 2014.

24. SMOLDERS E. Cadmium uptake by plants. International Journal of Occupational Medicine and Environmental Health, 14 (2), 177, 2001.

25. PAIS I., JONES J.B.JR. The handbook of trace elements. $1^{\text {st }}$. ed., St. Lucie Press, Boca Raton, Florida. 240, 1997.

26. OGUNDELE D.T., ADIO A.A., OLUDELE O.E. Heavy metal Concentrations in plants and soil along heavy traffic roads in North Central Nigeria. J. Environ. Anal. Toxicol. 5:6. DOI: 10.4172/2161-0525.1000334. 2015.

27. KHALID S., SHAHID M., NIZAI N.K., MURTAZA B., BIBI I., DUMAT C. A comparison of technologies for remediation of heavy metal contaminated soils. J. Geochem. Explor. 182, 247, 2017.

28. KHAN M.A., KHAN S., KHAN A., ALAM M. Soil contamination with cadmium, consequences and remediation using organic amendments. Sci Total Environ. 601, 602, 1591, 2017.

29. DOTANIYA M.L., RAJENDIRAN S., COUMAR M.V., MEENA V.D., SAHA J.K., KUNDU S., KUMAR A., PATRA A.K. Interactive effect of cadmium and zinc on chromium uptake in spinach grown in Vertisol of Central India. International journal of environmental science and technology, 15 (2), 441, 2018.

30. BENAVIDES M.P., GALLEGO M.S., TOMARO L.M. Cadmium Toxicity in Plants. Braz. Journal of Plant Physiology, 17 (1), 21, 2005.

31. SU Y., LIU J., LU Z., WANG X., ZHANG Z., SHI G. Effects of iron deficiency on subcellular distribution and chemical forms of cadmium in peanut roots in relation to its translocation. Environmental and Experimental Botany, 97, 40, 2014.

32. HE B.Y., YU D.P., CHEN Y., SHI J.L., XIA Y., LI Q.S., WANG L.L., LING L., ZENG E.Y. Use of low-calcium cultivars to reduce cadmium uptake and accumulation in edible amaranth (Amaranthus mangostanus L.). Chemosphere, 171, 588, 2017.

33. FAHAD S., HUSSAIN S., KHAN F., WU C., SAUD S., HASSAN S., AHMAD N., GANG D., ULLAH A., HUANG J. Effects of tire rubber ash and zinc sulfate on crop productivity and cadmium accumulation in five rice cultivars under field conditions. Environmental Science and Pollution Research, 22 (16), 12424, 2015.

34. RAHMAN A., NAHAR K., HASANUZZAMAN M., FUJITA M. Manganese-induced cadmium stress tolerance in rice seedlings: Coordinated action of antioxidant defense, glyoxalase system and nutrient homeostasis. Comptes rendus biologies, 339 (11-12), 462, 2016.

35. WU F., ZHANG G. Alleviation of cadmium-toxicity by application of zinc and ascorbic acid in barley. Journal of Plant Nutrition, 25 (12), 2745, 2002.

36. RAVINDRAN B., MUPAMBWA H.A., SILWANA S., MNKENI P.N. Assessment of nutrient quality, heavy metals and phytotoxic properties of chicken manure on selected commercial vegetable crops. Heliyon, 3 (12), e00493, 2017.

37. LEVENTOGLU H., ERDAL İ. Effect of high humic substance levels on growth and nutrient concentration of corn under calcareous conditions. Journal of plant nutrition, 37 (12), $2074,2014$.

38. UKPE A.R., CHOKOR A.A. Correlation between concentrations of some heavy metals in poultry feed and waste. Open Access Journal of Toxicology, 3 (2), 4, 2018.

39. PIERZYNSKI G.M., VANCE G.F., SIMS J.T. Soils and environmental quality. $3^{\text {rd }}$. ed., CRC press. UK, 584, 2005.

40. BOLAN N., KUNHIKRISHNAN A., THANGARAJAN R., KUMPIENE J., PARK J., MAKINO T., KIRKHAM M.B., SCHECKEL K. Remediation of heavy metal (loid) s contaminated soils - to mobilize or to immobilize? Journal of hazardous materials, 266, 141, 2014.

41. ZHOU T., WU L., LUO Y., CHRISTIE P. Effects of organic matter fraction and compositional changes on distribution of cadmium and zinc in long-term polluted paddy soils. Environmental Pollution, 232, 514, 2018.

42. KAMARI A., MOHD YUSOF, S.N., PUTRA W.P., ISHAK C.F., HASHIM N., MOHAMED A., PHILLIP E. Metal uptake in water spinach grown on contaminated soil amended with chicken manure and coconut tree sawdust. Environmental Engineering and Management Journal (EEMJ), 13(9). 2014.

43. ARROYO M.D.M.D., HORNEDO R.M.D.I., PERALTA F.A., ALMESTRE C.R., SÁNCHEZ J.V.M. Heavy metals concentration in soil, plant, earthworm and leachate from poultry manure applied to agricultural land. Revista Internacional de Contaminación Ambiental, 30 (1), 43, 2014. 
